\title{
Role of $\alpha \beta$ and $\gamma \delta$ T Cells in the Host Response to Salmonella Infection as Demonstrated in T-Cell-Receptor-Deficient Mice of Defined Ity Genotypes
}

\author{
BENNETT C. WEINTRAUB,${ }^{1} \dagger$ LARS ECKMANN,${ }^{2}$ SHARON OKAMOTO,${ }^{2}$ MARC HENSE,${ }^{1}+$ \\ STEPHEN M. HEDRICK, ${ }^{1}$ AND JOSHUA FIERER ${ }^{2,3 *}$ \\ Department of Biology, Cancer Center, ${ }^{1}$ and Department of Medicine, ${ }^{2}$ University of California, San Diego, \\ La Jolla, California 92093, and Infectious Diseases Section, Department of Veterans Affairs
}

Medical Center, San Diego, California $92161^{3}$

Received 8 November 1996/Returned for modification 13 December 1996/Accepted 29 March 1997

\begin{abstract}
Salmonella spp. are facultative intracellular bacteria which enter the body through the intestinal tract. We studied the roles of $T$ cells expressing either the $\alpha$ and $\beta$ chains or the $\gamma$ and $\delta$ chains of the T-cell receptor $(\alpha \beta$ T cells or $\gamma \delta$ T cells, respectively) in the host defense against Salmonella using mice genetically deficient in either $\alpha \beta \mathrm{T}$ cells, $\gamma \delta \mathrm{T}$ cells, or both T-cell subsets. These mutant strains of mice were infected orally or intraperitoneally with Salmonella dublin, and the progression of the disease was monitored by determining bacterial numbers in the feces, gut wall, Peyer's patches, mesenteric lymph nodes, spleen, and liver. Since susceptibility to Salmonella infection in mice is strongly affected by the alleles at the Ity locus, T-cell-mutant mice with either the Ity-sensitive or Ity-resistant phenotype were tested for resistance to $S$. dublin infection. We found that even though large numbers of intraepithelial and mucosal $\alpha \beta$ and $\gamma \delta \mathrm{T}$ cells populate the normal intestine, they have no role in controlling the invasion of $S$. dublin into the intestine or the subsequent bacterial replication in the Peyer's patches or gut wall. Furthermore, systemic infections were equally severe for the first 6 days in normal, $\alpha \beta$ T-cell-deficient, and $\gamma \delta$ T-cell-deficient mice, and $\alpha \beta$ but not $\gamma \delta$ T cells were required for clearance of $S$. dublin, regardless of the Ity phenotype. However, mice that lacked both T-cell subsets had higher bacterial counts in their livers 15 to 18 days after infection than did $\alpha \beta$ T-cell-deficient mice, suggesting that $\gamma \delta \mathrm{T}$ cells can contribute to acquired immunity to $S$. dublin.
\end{abstract}

Nontyphoid Salmonella spp. including S. typhimurium, S. dublin, $S$. choleraesuis, and $S$. enteritidis cause a spectrum of diseases in humans ranging from self-limited gastrointestinal infections to systemic infections with high mortality (38). $S$. dublin, which is host adapted to bovines, can cause severe systemic disease in humans, and the incidence of $S$. dublin infections has increased more than 10 -fold over the last 2 decades (10). Like $S$. typhimurium, $S$. dublin efficiently infects mice, which are commonly used as a model to study the pathogenesis of the infection and the host response to Salmonella (16).

Multiple bacterial and host factors determine the outcome of Salmonella infections. An important determinant of the innate host response to Salmonella is the Nrampl gene, which is located at the Ity/ $\mathrm{Bcg} / \mathrm{Lsh}$ locus on mouse chromosome 1 (36). Nramp1 encodes a protein that belongs to a family of integral membrane proteins with 10 highly conserved transmembrane domains (42). Nrampl genes which have a point mutation at nucleotide position 596 resulting in a glycine to aspartate substitution are susceptible not only to infection with nontyphoid Salmonella (e.g., they have the Ity ${ }^{s}$ phenotype) but also to Mycobacterium bovis (BCG) and Leishmania donovani

\footnotetext{
* Corresponding author. Mailing address: Infectious Diseases Section (111F), Department of Veterans Affairs Medical Center, $3350 \mathrm{La}$ Jolla Village Dr., San Diego, CA 92161. Phone: (619) 552-7446. Fax: (619) 552-4398. E-mail: jfierer@ucsd.edu.

$\dagger$ Present address: Howard Hughes Medical Institute, Stanford University, Stanford, CA 94305-5428.

$\ddagger$ Present address: Department of Cell Biology and Immunology, National Research Center for Biotechnology, 38124 Braunschweig, Germany.
}

(41). Macrophages from Ity ${ }^{s}$ mice cannot efficiently kill Salmonella or L. donovani $(5,25)$, and in vivo Salmonella grow more rapidly in the livers and spleens of susceptible mice (1). Ity mice are $>10^{4}$-fold more susceptible than Ity ${ }^{r}$ mice to intraperitoneal (i.p.) infection with $S$. dublin (6).

Salmonella enter the body through the small intestine and colon. Following penetration of the epithelial barrier, Salmonella are taken up by phagocytic cells in Peyer's patches (PP) and the lamina propria. Bacteria then spread to the mesenteric lymph nodes (MLN) and from there to systemic sites, most importantly the spleen and liver (3). In experimental infections, i.p. administration can be used to mimic the systemic phase of the infection, bypassing the entry of the bacteria through epithelial cells in the gut. Oral Salmonella infection differs in some aspects from i.p. infection, since it results in a different kinetics of bacterial counts early after infection. Furthermore, the invading bacteria depend on a set of invasionrelated genes after oral infection that are not required for systemic virulence (39).

During the early, innate host response against Salmonella, high levels of gamma interferon (IFN- $\gamma$ ) and tumor necrosis factor alpha (TNF- $\alpha$ ) are produced (6), and in vivo neutralization of either IFN- $\gamma$ or TNF- $\alpha$ with antibodies severely compromises the host's ability to control the infection $(28,29$, $34,40)$. It is not clear whether $\mathrm{T}$ cells, especially those in the gut, i.e., intraepithelial lymphocytes (IELs) and lamina propria $\mathrm{T}$ cells, are important for production of these critical cytokines during the early phase of infection or if they influence the immune response to Salmonella through other mechanisms. IELs are particularly interesting in this regard, since they are potentially the first $\mathrm{T}$ cells to interact with Salmonella during gut invasion. IELs are in a position to play a role early in 

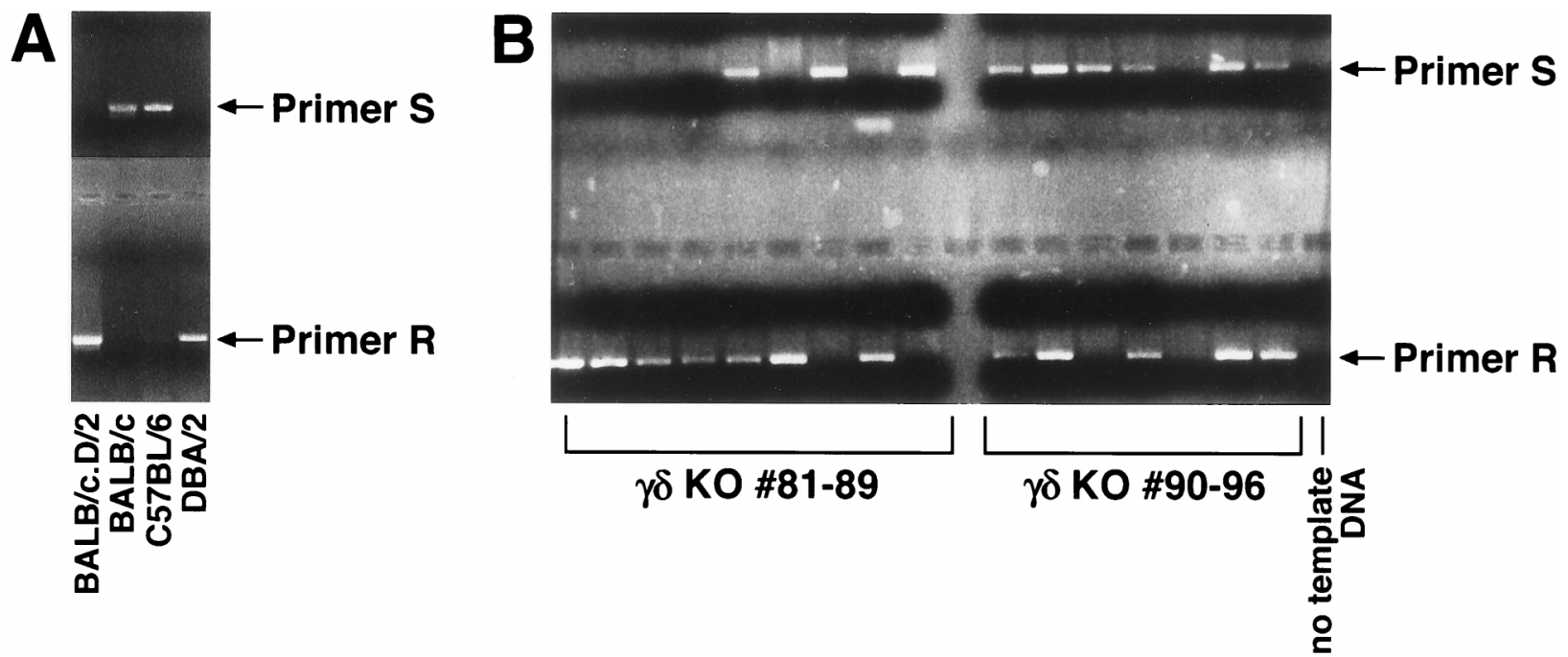

FIG. 1. Typing mice for Ity genotype by using PCR. DNA from tails was amplified by PCR by using a common downstream primer and either Primer S containing the nucleotide associated with Ity ${ }^{s}$ genotype or Primer R containing the nucleotide associated with the Ity ${ }^{r}$ genotype. Aliquots of the PCRs were run on a $1 \%$ agarose-ethidium bromide gel. DNA from BALB/c, BALB/c.D2 Ity congenics, DBA/2, and C57B1/6 mice (A) and DNA from TCR $\delta$ knockout mice that we bred (B) are shown. TCR $\delta^{-1-} 94$ mice did not yield a product and could not be typed in this round of PCR analysis. TCR $\delta^{-1-} 87,89$, and 92 mice are Ity and the rest are Ity since the presence of both bands indicates that mice are heterozygous at the Ity locus (TCR $\delta^{-1-} 85,90,91,93,95$, and 96 ), resulting in an Ity ${ }^{r}$ phenotype.

infection because IELs have some properties of activated $\mathrm{T}$ cells, such as large size and expression of the T-cell activation marker CD69 (24), and because some IEL subsets produce keratinocyte growth factor (2), which may be important for wound healing and protection of epithelial surfaces. IELs in mice are composed of similar percentages of $\alpha \beta$ and $\gamma \delta$ T cells (37), so that either $\alpha \beta$ or $\gamma \delta$ IELs could affect invasion or growth of Salmonella.

The clearance of bacteria from tissues in the later stages of Salmonella infection is dependent on T cells, as athymic nude mice or T-cell-depleted mice survive the initial stages but fail to resolve the infection $(17,26,27,33,35)$. Resolution of infection is potentially mediated by $\alpha \beta, \gamma \delta$, or both subsets of $\mathrm{T}$ cells. Several studies have addressed the relative role of $\alpha \beta$ and $\gamma \delta$ T cells in Salmonella infection. Humans infected with Salmonella typhi have an increased percentage of circulating $\gamma \delta$ $\mathrm{T}$ cells (15). In mice, Emoto and colleagues observed an influx of $\gamma \delta$ T cells into the peritoneal cavity after i.p. injection of $S$. choleraesuis (7) and suggested that this influx was greater in Ity ${ }^{r}$ mice than $I t y^{s}$ mice (8), but they did not establish in that report whether $\gamma \delta$ T cells protect against Salmonella infection. Mixter et al. used antibodies to deplete Ity ${ }^{s}$ mice of $\alpha \beta$ T cells or $\gamma \delta \mathrm{T}$ cells and found a protective role for both T-cell subsets in $S$. enteritidis infection (30). In contrast, Emoto et al. found that mice genetically deficient for $\gamma \delta \mathrm{T}$ cells controlled Salmonella infection better than wild-type controls (9), but these authors did not control for the Ity genotype of the mice.

Because of these seemingly contradictory results, we studied the role of $\alpha \beta$ and $\gamma \delta$ T cells in the resistance to $S$. dublin using mutant mice which were genetically deficient for $\alpha \beta$ T cells, $\gamma \delta$ $\mathrm{T}$ cells, or both T-cell subsets and which were segregated based on their Ity genotype. We found that $\alpha \beta$ T cells, but not $\gamma \delta \mathrm{T}$ cells, are required for resolution of Salmonella infection in both Ity $^{r}$ and Ity ${ }^{s}$ mice. Neither $\alpha \beta$ nor $\gamma \delta$ T cells were important in limiting bacterial entry into the intestine or in slowing bacterial growth outside the intestine during the first 6 days after oral infection.

\section{MATERIALS AND METHODS}

Mice. Mutant and control mice were purchased from Jackson Laboratories (Bar Harbor, Me.). TCR $\alpha^{-/-}$mice were typed by Southern blotting as previously described (32). TCR $\delta^{-1-}$ mice were typed by PCR as previously described (18). For Ity typing, tail DNA was amplified by PCR to yield a 210-bp fragment by using $10 \mathrm{pmol}$ of a common $3^{\prime}$ primer (5'-ACAGCCCGGACAGGTGGG-3') and 10 pmol of either a $5^{\prime}$ primer specific for the Ity $^{s}$ genotype $\left(5^{\prime}\right.$-ACGCATC CCGCTGTGGGA- $\left.3^{\prime}\right)$ or a $5^{\prime}$ primer specific for the Ity $^{r}$ genotype $\left(5^{\prime}\right.$-ACGCA TCCCGCTGTGGGG-3'). Reaction mixtures containing $1.5 \mathrm{mM} \mathrm{MgCl}$ were heated to $94^{\circ} \mathrm{C}$ for $3 \mathrm{~min}$; this was followed by 27 cycles of $20 \mathrm{~s}$ at $94^{\circ} \mathrm{C}, 20 \mathrm{~s}$ at $60^{\circ} \mathrm{C}, 20 \mathrm{~s}$ at $72^{\circ} \mathrm{C}$, and a final extension at $72^{\circ}$ for 7 minutes. Ity $\mathrm{TCR}^{-1-}$ and TCR $\delta^{-1-}$ mice were bred to Ity 129 strain mice, and F1 mice were bred to each other or to the parental mutant strain to obtain Ity $^{r}$ mutant mice. Mice used for experiments were $>6$ weeks old. Mice were housed under specific pathogen-free conditions in microisolator cages with sterile food and water.

Bacterial strains. The following strains of $S$. dublin were used: Lane, a patient isolate; Lane pSD6, a kanamycin-resistant derivative; and LD842, a plasmidcured derivative of Lane (4). Lane pSD6 has Tn5 inserted in the virulence plasmid outside the $s p v$ regulon, and it is a fully virulent $S$. dublin strain (4). After overnight culture in tryptic soy broth (Difco, Detroit, Mich.), bacteria were washed and resuspended in $0.1 \mathrm{M}$ sodium bicarbonate for oral infection or $0.9 \%$ $\mathrm{NaCl}$ for i.p. injection. Mice were fasted overnight before oral infection (16) and were inoculated with the indicated number of $S$. dublin in a $200-\mu$ l volume for feeding or a $100-\mu$ l volume for i.p. injection.

Salmonella colony counts. After the mice were sacrificed, various organs were removed. The distal portion of the small intestine was removed and flushed of contents. The three most distal PP of the small intestine were removed as previously described (16). A 3-cm-long piece of the remaining small intestine lacking PP was used in some experiments to determine bacterial numbers in the gut wall. Feces and pieces of liver were weighed before grinding. Each organ was ground in a homogenizer (Tri-R Instruments, Rockville Center, N.Y.) and then plated at various dilutions in saline on either tryptic soy agar (Difco) or Hektoen Enteric agar (Becton Dickinson, Cockeysville, Md.) with kanamycin $(20 \mu \mathrm{g} / \mathrm{ml})$. $\mathrm{CFU}$ were counted after incubation at $37^{\circ} \mathrm{C}$ overnight. Statistical analysis was performed with StatView 4.0 (Abacus Concepts, Berkeley, Calif.) by using unpaired Student's $t$ tests.

IFN- $\boldsymbol{\gamma}$ ELISA. Blood was collected from the tail vein of mice immediately prior to sacrificing. Levels of IFN- $\gamma$ in the serum were determined by enzymelinked immunosorbent assay (ELISA) as described previously (6).

\section{RESULTS}

Typing of mutant mice for Ity genotype. Alleles of the Nrampl gene at the Ity locus are important for determining resistance and susceptibility to Salmonella infection in mice (41). Since the mice used for gene targeting were of mixed 

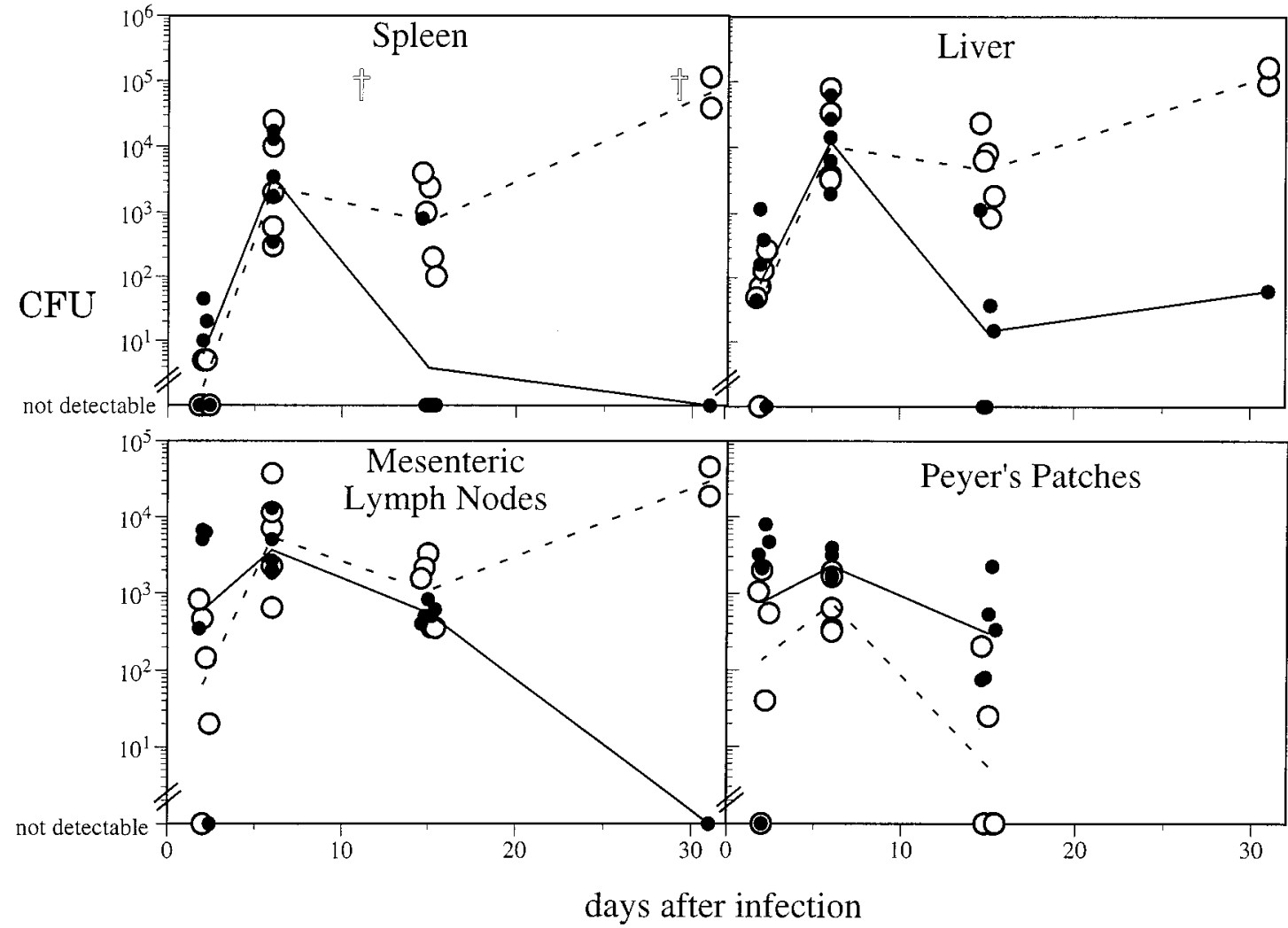

FIG. 2. Oral infection of $I t^{r} \alpha \beta$ T-cell-deficient mice and wild-type littermates. Mice were fed $5.6 \times 10^{7} \mathrm{CFU}$ of $S$. dublin Lane pSD6 and sacrificed on the indicated days after infection, and CFU were determined. Circles represent counts from individual mice and lines represent the geometric means of the mice in the groups. $(\mathrm{O}$, $\mathrm{TCR} \alpha^{-1-}$ mice; $\bullet$, wild-type littermates. Two mutant mice ( $f$, top left graph) died during the experiment on day 12 and day 28, and Salmonella counts were not determined for these mice. No wild-type mice died during the experiment.

genetic background, i.e., 129 mice are Ity $^{r}$ and C57BL/6 (B6) mice are Ity $^{\text {, }}$, we developed a PCR-based assay to determine the Ity genotype of the mutant mice. Since Taq polymerase cannot extend a primer that does not anneal to the final nucleotide, two sense PCR primers were designed which have a $3^{\prime}$ nucleotide complementary to either the wild-type or mutant base in the Nramp1 gene. A common antisense primer complementary to a region 210 bp downstream in the Nramp1 gene was used to generate PCR products. By using these two primer pairs the mutant and wild-type Nramp1 alleles could be accurately distinguished, as determined by appropriate amplification of the product associated with the Ity ${ }^{s}$ but not the Ity ${ }^{r}$ allele in stock B6 mice and amplification of the Ity product but not the Ity ${ }^{s}$ product in stock 129 mice. Since Nramp2 has significant sequence homology with Nramp1 in this region (1), it was important to establish the specificity of the primers under the conditions we used to amplify the DNA. Figure 1A shows that the appropriate primer amplified an Nrampl gene from each of four strains of known Ity phenotypes. Since the BALB/c.D2 congenic mice have the same Nramp2 allele but different alleles of Nramp1, the fact that the two primers differentiate between these congenic strains supports the conclusion that the primers are specific for Nramp1. An example of PCR amplification of tail DNA from $\mathrm{TCR} \delta^{-/-}$mice is shown in Fig. $1 \mathrm{~B}$.

Typing of the stock $\mathrm{TCR} \alpha^{-1-}, \mathrm{TCR} \beta^{-1-}$, and $\mathrm{TCR} \delta^{-1-}$ mice showed that they were all Ity ${ }^{s}$. In order to generate Ity ${ }^{r}$ mutant mice, Ity $^{s}$ mice were back crossed to 129 mice, and the resultant F1 mice were bred to each other or to the parental mice.

$\alpha \beta$ T cells but not $\gamma \delta$ T cells are required to resolve $S$. dublin infection in Ity $^{\boldsymbol{r}}$ mice. To examine the role of $\alpha \beta \mathrm{T}$ cells in controlling Salmonella infection, Ity ${ }^{r} \alpha \beta$ T-cell-deficient mice and wild-type $I_{t y}{ }^{r}$ littermates were orally infected with $S$. $d u b$ lin, and the severity of infection was monitored by determining bacterial numbers in the gut wall, PP, MLN, spleen, and liver (Fig. 2). Wild-type mice had begun to resolve the infection in the liver and spleen by day 15 p.i. and between day 15 and 30 in the MLN, whereas the bacterial counts in $\alpha \beta$ T-cell-deficient mice continued to increase throughout the infection, and some T-cell-deficient mice died of the infection. The results of PP cultures are hard to interpret since those structures were very small in the $\alpha \beta$ T-cell-deficient mice, making them hard to find and remove in their entirety. This result demonstrates that $\alpha \beta$ T cells are necessary to resolve Salmonella infection. However, no difference was observed between mutant and control mice during the first 6 days of infection, indicating that $\alpha \beta$ T cells are important only later in infection.

In contrast to the requirement for $\alpha \beta \mathrm{T}$ cells, comparison of Ity $^{r} \gamma \delta \mathrm{T}$-cell-deficient mice with Ity $^{r}$ wild-type littermates showed that $\gamma \delta$ T cells are not necessary for resolving $S$. dublin infection. Throughout the 38-day experiment, no significant difference between $\gamma \delta$ T-cell-deficient and wild-type mice was observed in the number of bacteria in any organ cultured (Fig. 3 ), including the intestinal wall, the contents of the terminal 

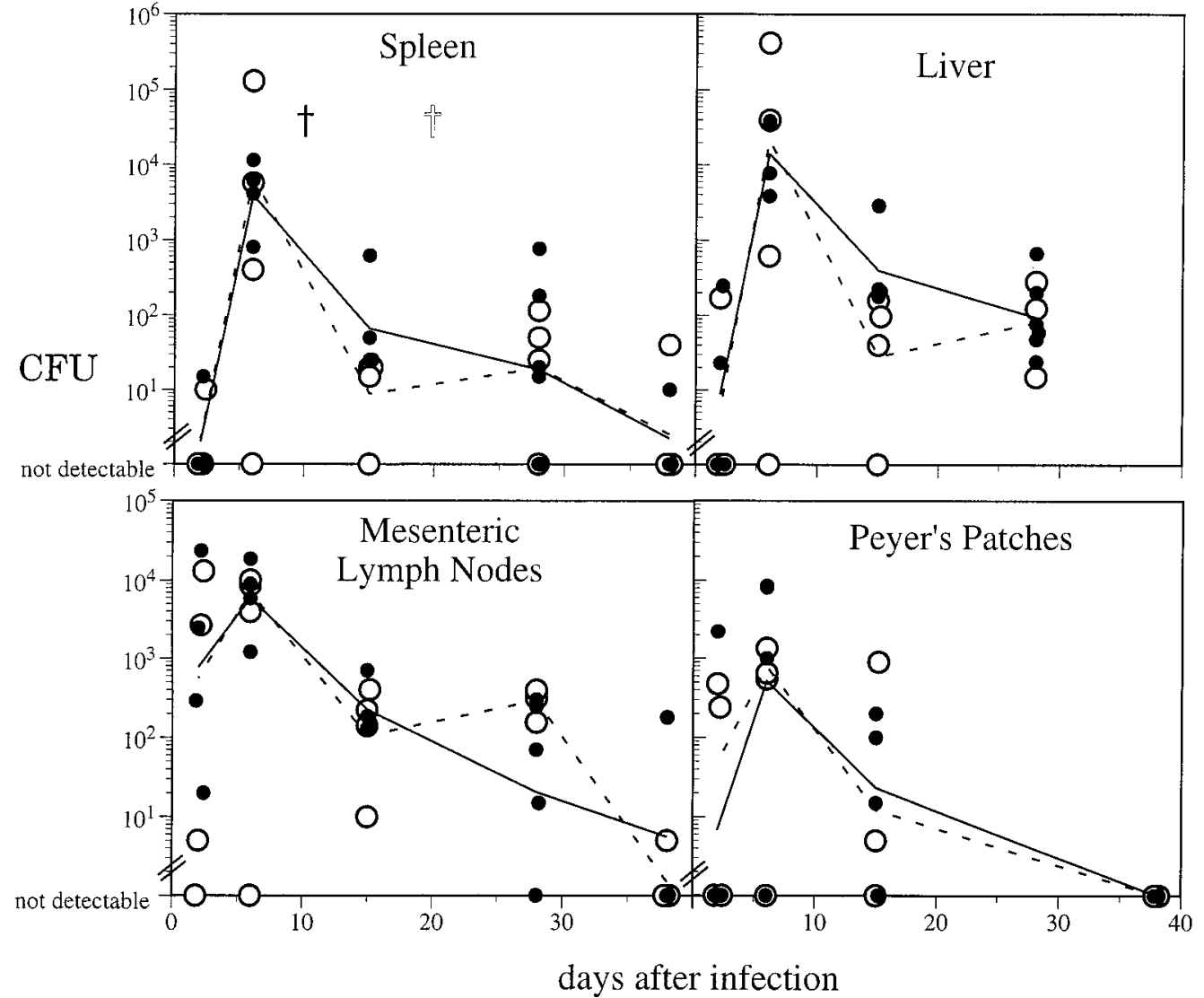

FIG. 3. Oral infection of Ity ${ }^{r} \gamma \delta$ T-cell-deficient mice and wild-type littermates. Mice were fed $3.3 \times 10^{7} \mathrm{CFU}$ of $S$. dublin Lane pSD6. Methods and symbols are as described in the legend for Fig. 2. $\bigcirc$, TCR $\delta^{-1-}$ mice; $\bullet$, wild-type littermates. Two mice died during the course of the experiment, a wild-type mouse on day 10 p.i. (t) and a mutant mouse on day 20 p.i. $(\uparrow)$.

ileum, and the feces (data not shown). (This experiment was repeated once with the same result.)

Role of $\alpha \beta$ and $\gamma \delta \mathrm{T}$ cells in Ity ${ }^{s}$ mice infected with $S$. dublin. We then repeated the experiments using T-cell-deficient mice that were Ity $y^{s}$, including TCR $\gamma^{-1-} \times \mathrm{TCR} \beta^{-1-}$ mice. Since $S$. dublin Lane kills Ity ${ }^{s}$ mice 6 to 8 days after oral infection, we could only study earlier time points in this experiment. The infection was equally severe in all mice, regardless of their T-cell status, on days 2 and 4 after infection. We also found no significant difference in CFU in the livers, spleens, MLN, PP, intestinal walls of the ileum, and the feces (data not shown). By day 4 the geometric means of CFU were $5 \times 10^{4}$ to $5 \times 10^{5}$ in the spleen and $8 \times 10^{4}$ to $2 \times 10^{5}$ per $g$ of liver in wild-type and all mutant mice.

Since Salmonella can be detected very rapidly in the distal ileum after feeding (within 15 to $20 \mathrm{~min}$ ) and $\gamma \delta \mathrm{T}$ cells in the gut could potentially limit the initial invasion of Salmonella into the gut wall, we sacrificed another group of mice relatively early (4 to $9 \mathrm{~h}$ ) after oral infection to find evidence for increased intestinal invasion in the $\gamma \delta \mathrm{T}$-cell-deficient mice. However, no significant difference was found in the bacterial counts in the gut wall or PP between $\gamma \delta$ T-cell-deficient mice and wild-type littermates regardless of the Ity phenotype (Fig. 4). We also cultured the contents of the terminal ileum and the feces and found no differences in CFU per gram between the groups (data not shown). These results show that $\gamma \delta$ IELs and other intestinal $\gamma \delta$ T cells do not affect the invasion of $S$. dublin into the gut wall or PP after oral infection.
Even though there was no detectable difference in the ability of $\gamma \delta$ T-cell-deficient mice and wild-type Ity $^{r}$ mice to control Salmonella infection (Fig. 3), nor any difference for the first 4 days in $I t y^{s}$ mice, it was possible that $\gamma \delta \mathrm{T}$ cells had a function in controlling Salmonella infection later in infection that was not apparent because $\alpha \beta \mathrm{T}$ cells compensated for their absence. To test this possibility, we compared Ity ${ }^{s}$ TCR $\beta^{-1-}$ mice with Ity $\mathrm{TCR}^{-1-} \times \mathrm{TCR}^{-1-}$ mice. Since the doubly deficient mice were available only with the Ity ${ }^{s}$ phenotype, we infected the mice with $S$. dublin LD842, an isogenic plasmidcured strain that has a $50 \%$ lethal dose $\left(\mathrm{LD}_{50}\right)$ of $10^{4}$ in Ity $^{\mathrm{s}}$ mice after i.p. infection (11). The i.p. route was chosen for these experiments to reduce mouse-to-mouse variability, and this experiment focused on the later stages of infection, which are similar for oral and i.p. infection. No significant difference among TCR $\beta^{-1-} \times \mathrm{TCR}^{-1-}, \mathrm{TCR} \beta^{-1-}$, and wild-type mice in the bacterial counts in spleens or livers was detected on day 10 p.i. in two independent experiments (data not shown). Furthermore, as expected, in each of four independent experiments, mice lacking $\alpha \beta \mathrm{T}$ cells or all T cells had significantly more $S$. dublin in their spleens and livers than wild-type mice after 16 to 25 days of infection (Fig. 5). However, mice with no $\alpha \beta$ or $\gamma \delta$ T cells had, on average, about 10-fold more Salmonella in their spleens and livers than $\alpha \beta$ T-cell-deficient mice (Fig. 5). Although the two groups overlapped, the difference between the groups was significant $(P<0.01)$. In addition, 2 of $24 \mathrm{TCR}^{-1-} \times \mathrm{TCR}^{-1-}$ mice died during the experiment, whereas none of the $22 \mathrm{TCR} \beta^{-1-}$ mice died. Ity $^{s}$ mice lacking 


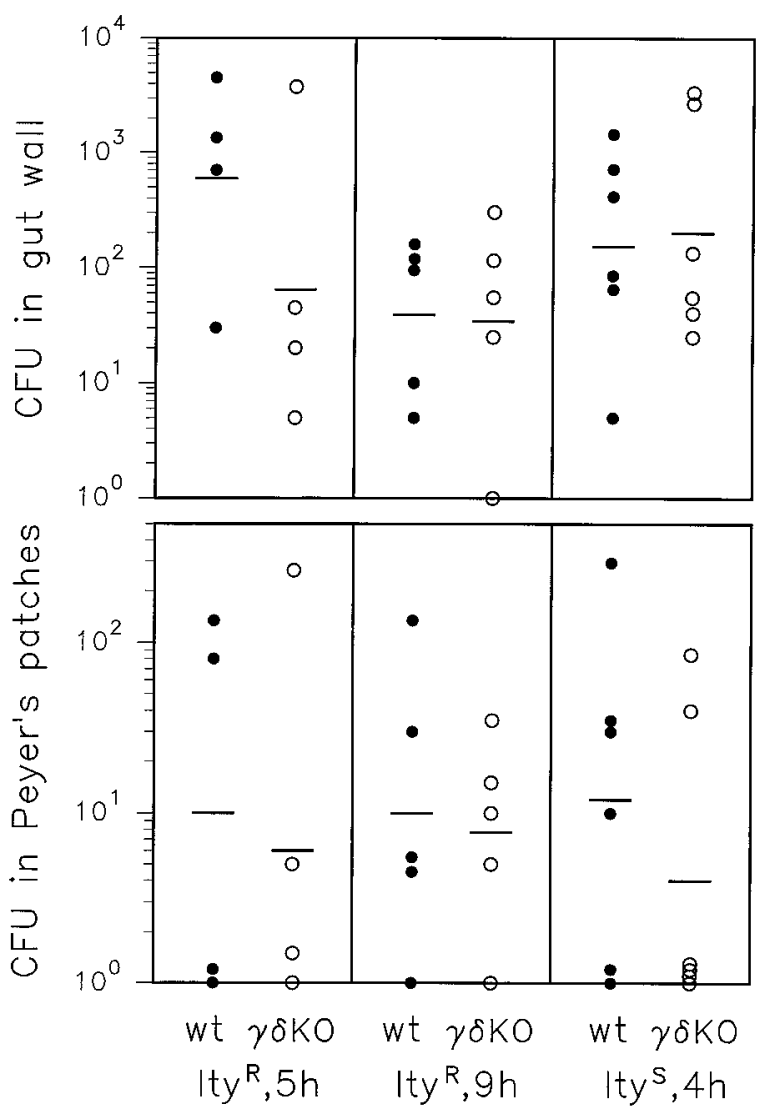

FIG. 4. Salmonella in the gut wall and PP early after oral infection. Mice were infected orally with $S$. dublin Lane $\left(2.6 \times 10^{7} \mathrm{CFU}\right.$ for Ity ${ }^{r}$ mice and $1.3 \times$ $10^{7} \mathrm{CFU}$ for Ity ${ }^{5}$ mice). To determine bacterial counts in the gut wall, $3 \mathrm{~cm}$ of the distal end of the ileum was removed from the animal, all PP were removed from this piece, and the section was rinsed thoroughly with saline. In some experiments, gentamicin $(50 \mu \mathrm{g} / \mathrm{ml})$ was included in the saline rinse to kill extracellular Salmonella which had not invaded intestinal epithelial cells, but no differences in CFU were observed between samples rinsed with saline alone and those rinsed with saline containing gentamicin. To determine the number of bacteria in PP, the three most distal PP in the ileum were removed and rinsed thoroughly in saline. Data are individual results from 4 to 6 mice per group. $\bullet$, wild-type mice; $\bigcirc, \mathrm{TCR} \delta^{-1-}$ mice. The bars represent geometric means for each experimental group. Differences between mutant and wild-type mice were not significant ( $P \geq$ 0.4 by Student's $t$ test for all groups).

$\gamma \delta$ T cells cleared $S$. dublin LD842 infection as well as wild-type Ity $y^{s}$ mice (data not shown), demonstrating that the effect of $\gamma \delta$ $\mathrm{T}$ cells was revealed because of the absence of $\alpha \beta \mathrm{T}$ cells, not because Ity $^{s}$ mice were used or because $S$. dublin LD842 was the infectious agent. These results suggest that $\gamma \delta \mathrm{T}$ cells play a role in the resolution of Salmonella infections, although this effect is small compared to the role of $\alpha \beta \mathrm{T}$ cells and is detectable only in the absence of $\alpha \beta$ T cells.

IFN- $\boldsymbol{\gamma}$ production in T-cell-deficient mice. Since production of IFN- $\gamma$ is critical for clearance of Salmonella (34), we tested the ability of $\mathrm{TCR} \beta^{-1-}$ and $\mathrm{TCR} \beta^{-1-} \times \mathrm{TCR} \delta^{-1-}$ mice to produce IFN- $\gamma . \alpha \beta$ T-cell-deficient mice from the experiment shown in Fig. 2 produced levels of IFN- $\gamma$ that were comparable to those in wild-type mice in response to $S$. dublin infection (Table 1). In both strains of mice, serum IFN- $\gamma$ levels correlated with bacterial load, as was shown by Eckmann et al. (6). Furthermore, sera from both $\alpha \beta$ T-cell-deficient and $\alpha \beta$ and $\gamma \delta$ T-cell-deficient mice contained high levels of IFN- $\gamma$ following $S$. dublin LD842 infection (Table 1). These data show not only that IFN- $\gamma$ is produced by cells other than $\mathrm{T}$ cells in response to infection, but also that IFN- $\gamma$ production is not sufficient to induce clearance of Salmonella infection in the absence of $\alpha \beta$ T cells.

\section{DISCUSSION}

In order to define the role of $\alpha \beta$ and $\gamma \delta \mathrm{T}$ cells in the host defense against Salmonella, we used mice lacking $\alpha \beta$ T cells, $\gamma \delta$ $\mathrm{T}$ cells, and both $\alpha \beta$ and $\gamma \delta \mathrm{T}$ cells. Several aspects of the immune response to Salmonella have been revealed in this study. First, the critical role of $\alpha \beta$ T cells was demonstrated, since $\alpha \beta$ T-cell-deficient mice were not able to resolve an oral infection with $S$. dublin regardless of their Ity phenotype. Second, $\gamma \delta \mathrm{T}$ cells do not contribute a unique function to the
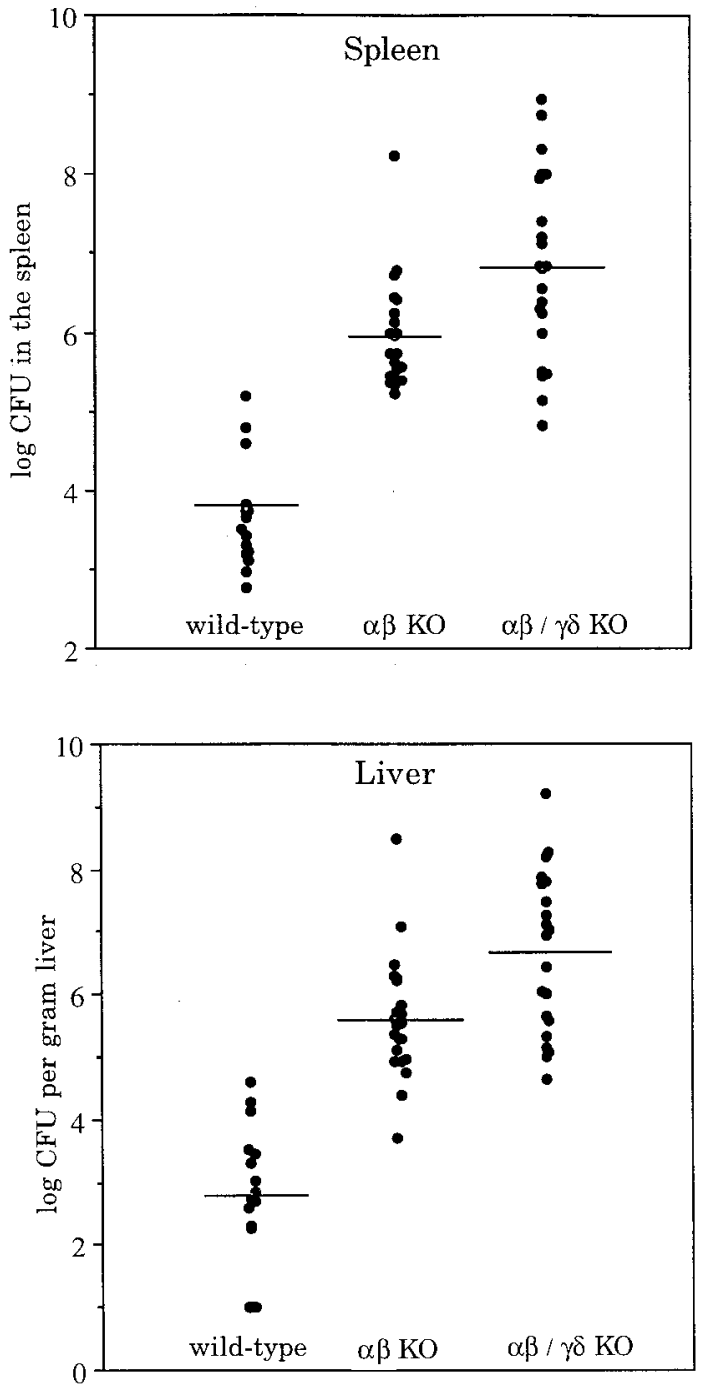

FIG. 5. i.p. infection of Ity $\alpha \beta$ T-cell-deficient, $\alpha \beta$ and $\gamma \delta$ T-cell-deficient, and wild-type control mice. Mice were injected i.p. with $3.5 \times 10^{3}$ to $4.0 \times 10^{3}$ CFU S. dublin LD842 in four independent experiments. TCR $\beta^{-1-}$ mice were from a B6 background while TCR $\beta^{-1-} \times \mathrm{TCR} \delta^{-1-}$ mice were from a mixed B6 and 129 background. Each point represents CFU from a single mouse from one of the four experiments. Two mice, both $\mathrm{TCR}^{-1-} \times \mathrm{TCR}^{-/-}$, died during the experiments on day 15 and day 20 p.i. and are not included in the figure. Differences between the mean log CFU in both the livers and spleens of $\mathrm{TCR} \beta^{-1-}$ mice compared to those of $\mathrm{TCR} \beta^{-/-} \times \mathrm{TCR} \delta^{-1-}$ mice 16 to 25 days after infection were significant at $P<0.01$ by Student's $t$ test. 
TABLE 1. Serum IFN- $\gamma$ levels in $S$. dublin-infected T-cell-subset-deficient mice ${ }^{a}$

\begin{tabular}{ccrccc}
\hline $\begin{array}{c}\text { Ity } \\
\text { pheno- } \\
\text { type }\end{array}$ & Mice & $\begin{array}{c}\text { Days } \\
\text { p.i. }\end{array}$ & CFU/spleen & CFU/g of liver & $\begin{array}{c}\text { Serum IFN- } \gamma \\
(\mathrm{pg} / \mathrm{ml})\end{array}$ \\
\hline $\mathrm{R}$ & $\mathrm{TCR} \alpha^{-/-}$ & 6 & $2.5 \times 10^{3}$ & $1.0 \times 10^{4}$ & $600 \pm 113$ \\
& & 15 & $7.2 \times 10^{2}$ & $4.6 \times 10^{3}$ & $308 \pm 128$ \\
& Wild-type & 6 & $3.4 \times 10^{3}$ & $1.2 \times 10^{4}$ & $965 \pm 430$ \\
$\mathrm{~S}$ & & 15 & $<10^{1}$ & $1.5 \times 10^{1}$ & $<300$ \\
& $\mathrm{TCR}^{-/-}$ & 20 & $4.2 \times 10^{5}$ & $4.9 \times 10^{4}$ & $645 \pm 151$ \\
& $\begin{array}{c}\text { TCR } \beta^{-/-} \times \\
\text {TCR } \delta^{-/}\end{array}$ & 20 & $2.5 \times 10^{7}$ & $1.5 \times 10^{7}$ & $560 \pm 282$ \\
& Wild-type & 20 & $2.0 \times 10^{3}$ & $1.7 \times 10^{1}$ & $<250$ \\
\hline
\end{tabular}

${ }^{a}$ Ity $^{r}$ mice were infected with $S$. dublin Lane as described in the legend to Fig. 2, and Ity ${ }^{s}$ mice were infected with S. dublin LD842 as described in the legend for Fig. 5. CFU are the geometric means of 4 to 5 mice. Serum IFN- $\gamma$ levels from four mice in each group were determined by ELISA, and values are means \pm standard errors.

${ }^{b} \mathrm{R}$, resistant, $\mathrm{S}$, sensitive.

immunity to Salmonella that cannot be compensated by $\alpha \beta \mathrm{T}$ cells. Thus, in mice with $\alpha \beta$ T cells, we could not demonstrate a role for $\gamma \delta \mathrm{T}$ cells either early in infection when innate immunity predominates or later during the acquired immune response. However, our data suggest that $\gamma \delta \mathrm{T}$ cells can play a role in the later stages of Salmonella infection, although this effect can be detected only in the absence of $\alpha \beta$ T cells. Taken together, this demonstrates that $\alpha \beta$ T cells can fully compensate for the lack of $\gamma \delta \mathrm{T}$ cells, but the converse is true only to a very limited extent. Third, we show that neither $\alpha \beta$ nor $\gamma \delta \mathrm{T}$ cells, in the intestine or in other sites, contribute to limiting bacterial entry into the intestine or bacterial growth during the early phase of Salmonella infection. This is further supported by the finding that Ity $\mathrm{Rag}^{-1-}$ mice, which lack all $\mathrm{B}$ and $\mathrm{T}$ cells, did not show increased severity of disease during the first 6 days of infection with $S$. dublin (data not shown). Similarly, a recent study from Guilloteau and colleagues, who infected SCID mice, which also lack all B and T cells, i.p. with $S$. dublin came to the same conclusion (14).

Two recent reports addressed the role of $\alpha \beta$ and $\gamma \delta$ T cells in Salmonella infection. One concludes that both $\alpha \beta$ and $\gamma \delta \mathrm{T}$ cells are protective against Salmonella, while the other concludes that $\gamma \delta \mathrm{T}$ cells increase susceptibility to Salmonella infection. Emoto et al. found that $\gamma \delta \mathrm{T}$-cell-deficient mice are more resistant to $S$. choleraesuis infection than wild-type mice (9). However, Emoto's report contains no indication that their mice were categorized on the basis of Ity phenotype. Since the mice they used could have been heterozygous at the Ity locus, and since their groups contained small numbers of mice, variable distribution of the Ity phenotypes between the wild-type and $\gamma \delta$ T-cell-deficient mice could account for their results. Other possible explanations for the difference between Emoto et al.'s results and ours, such as differences in response to $S$. choleraesuis and S. dublin, cannot be ruled out.

The other report, by Mixter and colleagues (30), showed that Ity $^{s}$ mice depleted of either $\alpha \beta$ or $\gamma \delta \mathrm{T}$ cells by the injection of anti-T-cell-receptor antibodies are more susceptible to oral infection with $S$. enteritidis, as measured by lower $\mathrm{LD}_{50}$ values determined 14 days after infection. Since we assessed resistance by measuring bacterial counts in various organs and did not determine $\mathrm{LD}_{50}$, Mixter et al.'s data could be reconciled with our findings if T-cell-deficient mice die with fewer numbers of Salmonella in the liver and spleen than wild-type mice. We tested this possibility and found that TCR $\beta^{-1-}, \mathrm{TCR} \delta^{-1-}$, and wild-type mice with an Ity ${ }^{s}$ phenotype all die with approx- imately $3 \times 10^{7} \mathrm{CFU}$ per spleen (data not shown). Therefore, we do not favor the hypothesis that T-cell-deficient mice have a different cause of death than wild-type mice. We suspect that some of the differences in $\mathrm{LD}_{50}$ in Mixter's experiments were due to a secondary effect of antibody-mediated depletion of large numbers of cells, rather than being directly due to lack of $\alpha \beta$ or $\gamma \delta$ T cells, but there may also be differences between the host responses to $S$. enteritidis and $S$. dublin.

Studies similar to ours using Listeria monocytogenes, BCG, and Mycobacterium tuberculosis reveal some similarities but also some interesting differences among the immune responses to different facultative intracellular bacteria. Mombaerts and colleagues (31) showed that $\alpha \beta$ T-cell-deficient and $\gamma \delta$ T-celldeficient mice can resolve Listeria infection but that mice without any $\mathrm{T}$ cells $\left(\mathrm{Rag}-1^{-1-}\right.$ or TCR $\left.\beta^{-1-} \times \mathrm{TCR} \delta^{-1-}\right)$ could not resolve infection. This shows that either $\alpha \beta$ or $\gamma \delta$ T cells are sufficient to clear Listeria infection, whereas our data show that $\alpha \beta$ but not $\gamma \delta \mathrm{T}$ cells are sufficient to clear Salmonella. Another difference between the immune responses to Listeria and Salmonella is that the $\alpha \beta \mathrm{T}$-cell response to Listeria primarily involves $\mathrm{CD}^{+}$cytotoxic T cells (22), whereas $\mathrm{CD}^{+}{ }^{+}$helper T cells are more important for the host response to Salmonella (33).

The importance of $\alpha \beta$ and $\gamma \delta$ T cells was also studied in response to infection with BCG and $M$. tuberculosis $(19,23)$. In BCG infection, as in Salmonella infection, $\alpha \beta$ T cells but not $\gamma \delta$ $\mathrm{T}$ cells play a critical role in controlling infection. Studies with major histocompatibility class I- or class II-deficient mice show that $\mathrm{CD}^{+} \alpha \beta \mathrm{T}$ cells are more important than $\mathrm{CD}^{+} \alpha \beta \mathrm{T}$ cells in the clearance of BCG (21). Resistance to $M$. tuberculosis, a mycobacterium closely related to, but more virulent than $\mathrm{BCG}$, is dependent upon both $\mathrm{CD}^{+}$and $\mathrm{CD}^{+} \alpha \beta \mathrm{T}$ cells $(12,13) . \gamma \delta$ T-cell-deficient mice infected with $M$. tuberculosis have slightly higher CFU than wild-type mice, implying that $\gamma \delta \mathrm{T}$ cells are more important for clearance of $M$. tuberculosis than BCG. Together with the Salmonella and Listeria results, these findings suggest a correlation between the importance of $\gamma \delta \mathrm{T}$ cells and the relative importance of $\mathrm{CD} 8^{+}$ versus $\mathrm{CD}^{+}{ }^{+} \alpha \beta \mathrm{T}$ cells. One explanation for these data is that $\gamma \delta \mathrm{T}$ cells are able to functionally compensate for $\mathrm{CD}^{+} \alpha \beta \mathrm{T}$ cells but not $\mathrm{CD}^{+} \alpha \beta$ T cells.

The mechanism of action of $\alpha \beta$ and $\gamma \delta$ T cells in host defense against Salmonella is poorly understood. Bacteria are eliminated in the late stages of infection mainly by activated macrophages, which are stimulated by a combination of bacterial signals, e.g., lipopolysaccharide, and T-cell-mediated signals. We show here that T-cell-deficient mice produce large amounts of IFN- $\gamma$ after Salmonella infection, indicating that T cells are not an important source of this cytokine during Salmonella infection. Presumably, IFN- $\gamma$ is produced by NK cells in Salmonella-infected mice, as has been proposed for early Listeria infection (20). However, despite the continued production of IFN- $\gamma$, mutant mice infected with Salmonella had a progressive infection and eventually died. Macrophages in Tcell-deficient mice may not be able to be activated by IFN- $\gamma$ (or other T-cell cytokines), or T-cell surface ligands may be required to fully activate macrophages. Alternatively, the contribution of $\mathrm{T}$ cells to the immune response against Salmonella may also involve functions that are independent of macrophages.

\section{ACKNOWLEDGMENTS}

We thank Martin F. Kagnoff for helpful advice and discussion. We thank Antonis Vassiloyanakopoulos, Tomoko Yamamoto, Brian Helmich, and Jennifer R. Smith for excellent technical assistance, and David Schwarz for critically reading this manuscript. 
This work was supported in part by National Institutes of Health grant P07DK35108 and a grant from the Research Service of the Department of Veterans Affairs. L. Eckmann is a recipient of a Career Development Award of the Crohn's and Colitis Foundation of America. M. Hense was supported by a fellowship from the German Academic Exchange Service (DAAD; HSPII).

\section{REFERENCES}

1. Benjamin, W. H., Jr., P. Hall, S. J. Roberts, and D. E. Briles. 1990. The primary effect of the Ity locus is on the rate of growth of Salmonella typhimurium that are relatively protected from killing. J. Immunol. 144:31433151.

2. Boismenu, R., and W. L. Havran. 1994. Modulation of epithelial cell growth by intraepithelial gamma delta T cells. Science 266:1253-1255.

3. Carter, P. B., and F. M. Collins. 1974. The route of enteric infection in normal mice. J. Exp. Med. 139:1189-1203.

4. Chikami, G. K., J. Fierer, and D. G. Guiney. 1985. Plasmid-mediated virulence in Salmonella dublin demonstrated by use of a Tn5-orit construct. Infect. Immun. 50:420-424.

5. Crocker, P. R., J. M. Blackwell, and D. J. Bradley. 1984. Expression of the natural resistance gene $L s h$ in resident liver macrophages. Infect. Immun. 43:1033-1040.

6. Eckmann, L., J. Fierer, and M. F. Kagnoff. 1996. Genetically resistant (Ity ${ }^{\mathrm{r}}$ ) and susceptible $\left(\right.$ Ity $\left.^{\mathrm{s}}\right)$ congenic mouse strains show similar cytokine responses following infection with Salmonella dublin. J. Immunol. 156:2894-2900.

7. Emoto, M., H. Danbara, and Y. Yoshikai. 1992. Induction of gamma/delta T cells in murine salmonellosis by an avirulent but not by a virulent strain of Salmonella choleraesuis. J. Exp. Med. 176:363-372.

8. Emoto, M., T. Naito, R. Nakamura, and Y. Yoshikai. 1993. Different appearance of gamma delta T cells during salmonellosis between $\operatorname{Ity}^{\mathrm{r}}$ and Ity ${ }^{\mathrm{s}}$ mice. J. Immunol. 150:3411-3420.

9. Emoto, M., H. Nishimura, T. Sakai, K. Hiromatsu, H. Gomi, S. Itohara, and Y. Yoshikai. 1995. Mice deficient in $\gamma \delta \mathrm{T}$ cells are resistant to lethal infection with Salmonella choleraesuis. Infect. Immun. 63:3736-3738.

10. Fang, F. C., and J. Fierer. 1991. Human infection with Salmonella dublin. Medicine (Baltimore) 70:198-207.

11. Fierer, J., G. Chikami, L. Hatlen, E. J. Heffernan, and D. Guiney. 1988. Active immunization with LD842, a plasmid-cured strain of Salmonella dublin, protects mice against group D and group B Salmonella infection. J. Infect. Dis. 158:460-463.

12. Flynn, J. L., M. M. Goldstein, K. J. Triebold, and B. R. Bloom. 1993. Major histocompatibility complex class I-restricted T cells are necessary for protection against M. tuberculosis in mice. Infect. Agents Dis. 2:259-262.

13. Flynn, J. L., M. M. Goldstein, K. J. Triebold, B. Koller, and B. R. Bloom. 1992. Major histocompatibility complex class I-restricted T cells are required for resistance to Mycobacterium tuberculosis infection. Proc. Natl. Acad. Sci. USA 89:12013-12017.

14. Guilloteau, L. A., A. J. Lax, S. MacIntyre, and T. S. Wallis. 1996. The Salmonella dublin virulence plasmid does not modulate early T-cell responses in mice. Infect. Immun. 64:222-229.

15. Hara, T., Y. Mizuno, K. Takaki, H. Takada, H. Akeda, T. Aoki, M. Nagata, K. Ueda, G. Matsuzaki, Y. Yoshikai, and K. Nomoto. 1992. Predominant activation and expansion of $\mathrm{V}$ gamma 9-bearing gamma delta $\mathrm{T}$ cells in vivo as well as in vitro in Salmonella infection. J. Clin. Invest. 90:204-210.

16. Heffernan, E. J., J. Fierer, G. Chikami, and D. Guiney. 1987. Natural history of oral Salmonella dublin infection in BALB/c mice: effect of an 80-kilobasepair plasmid on virulence. J. Infect. Dis. 155:1254-1259.

17. Hormaeche, C. E., P. Mastroeni, A. Arena, J. Uddin, and H. S. Joysey. 1990. T cells do not mediate the initial suppression of a Salmonella infection in the RES. Immunology 70:247-250.

18. Itohara, S., P. Mombaerts, J. Lafaille, J. Iacomini, A. Nelson, A. R. Clarke, M. L. Hooper, A. Farr, and S. Tonegawa. 1993. T cell receptor delta gene mutant mice: independent generation of alpha beta $\mathrm{T}$ cells and programmed rearrangements of gamma delta TCR genes. Cell 72:337-348.

19. Ladel, C. H., C. Blum, A. Dreher, K. Reifenberg, and S. H. Kaufmann. 1995. Protective role of gamma/delta T cells and alpha/beta T cells in tuberculosis. Eur. J. Immunol. 25:2877-2881.

20. Ladel, C. H., C. Blum, and S. H. E. Kaufmann. 1996. Control of natural killer cell-mediated innate resistance against the intracellular pathogen Listeria monocytogenes by $\gamma / \delta \mathrm{T}$ lymphocytes. Infect. Immun. 64:1744-1749.

21. Ladel, C. H., S. Daugelat, and S. H. Kaufmann. 1995. Immune response to
Mycobacterium bovis bacille Calmette Guerin infection in major histocompatibility complex class I- and II-deficient knock-out mice: contribution of CD4 and CD8 T cells to acquired resistance. Eur. J. Immunol. 25:377-384.

22. Ladel, C. H., I. E. Flesch, J. Arnoldi, and S. H. Kaufmann. 1994. Studies with MHC-deficient knock-out mice reveal impact of both MHC I- and MHC II-dependent $\mathrm{T}$ cell responses on Listeria monocytogenes infection. J. Immunol. 153:3116-3122.

23. Ladel, C. H., J. Hess, S. Daugelat, P. Mombaerts, S. Tonegawa, and S. H. Kaufmann. 1995. Contribution of alpha/beta and gamma/delta T lymphocytes to immunity against Mycobacterium bovis bacillus Calmette Guerin studies with T cell receptor-deficient mutant mice. Eur. J. Immunol. 25:838846.

24. Lin, T., G. Matsuzaki, M. Umesue, K. Omoto, H. Yoshida, M. Harada, C. Singaram, K. Hiromatsu, and K. Nomoto. 1995. Development of TCR gamma delta CD4-CD8+ alpha alpha but not TCR-alpha beta CD4-CD8+ alpha alpha i-IEL is resistant to cyclosporin A. J. Immunol. 155:4224-4230.

25. Lissner, C. R., R. N. Swanson, and A. D. O'Brien. 1983. Genetic control of the innate resistance of mice to Salmonella typhimurium: expression of the Ity gene in peritoneal and splenic macrophages isolated in vitro. J. Immunol. 131:3006-3013.

26. Maier, T., and H. C. Oels. 1972. Role of the macrophage in natural resistance to salmonellosis in mice. Infect. Immun. 6:438-443.

27. Maskell, D. J., C. E. Hormaeche, K. A. Harrington, H. S. Joysey, and F. Y. Liew. 1987. The initial suppression of bacterial growth in a salmonella infection is mediated by a localized rather than a systemic response. Microb. Pathog. 2:295-305.

28. Mastroeni, P., J. N. Skepper, and C. E. Hormaeche. 1995. Effect of antitumor necrosis factor alpha antibodies on histopathology of primary Salmonella infections. Infect. Immun. 63:3674-3682.

29. Mastroeni, P., B. Villarreal-Ramos, and C. E. Hormaeche. 1992. Role of T cells, TNF alpha and IFN gamma in recall of immunity to oral challenge with virulent salmonellae in mice vaccinated with live attenuated rro $^{-}$salmonella vaccines. Microb. Pathog. 13:477-491.

30. Mixter, P. F., V. Camerini, B. J. Stone, V. L. Miller, and M. Kronenberg 1994. Mouse T lymphocytes that express a $\gamma \delta$ T-cell antigen receptor contribute to resistance to Salmonella infection in vivo. Infect. Immun. 62:4618 4621 .

31. Mombaerts, P., J. Arnoldi, F. Russ, S. Tonegawa, and S. H. E. Kaufmann. 1993. Different roles of alpha beta and gamma delta $\mathrm{T}$ cells in immunity against an intracellular bacterial pathogen. Nature 365:53-56.

32. Mombaerts, P., A. R. Clarke, M. A. Rudnicki, J. Iacomini, S. Itohara, J. J. Lafaille, L. Wang, Y. Ichikawa, R. Jaenisch, M. L. Hooper et al. 1992 Mutations in T-cell antigen receptor genes alpha and beta block thymocyte development at different stages. Nature 360:225-231.

33. Nauciel, C. 1990 . Role of $\mathrm{CD}^{+}{ }^{+} \mathrm{T}$ cells and T-independent mechanisms in acquired resistance to Salmonella typhimurium infection. J. Immunol. 145: $1265-1269$.

34. Nauciel, C., and F. Espinasse-Maes. 1992. Role of gamma interferon and tumor necrosis factor alpha in resistance to Salmonella typhimurium infection. Infect. Immun. 60:450-454.

35. O'Brien, A. D., and E. S. Metcalf. 1982. Control of early Salmonella typhimurium growth in innately Salmonella-resistant mice does not require functional T lymphocytes. J. Immunol. 129:1349-1351.

36. Plant, J., and A. A. Glynn. 1979. Locating Salmonella resistance gene on mouse chromosome 1. Clin. Exp. Immunol. 37:1-6.

37. Raulet, D. H. 1989. The structure, function, and molecular genetics of the gamma/delta T cell receptor. Annu. Rev. Immunol. 7:175-207.

38. Saphra, I., and J. W. Winter. 1957. Clinical manifestations of salmonellosis in man. An evaluation of 7779 human infections identified at the New York Salmonella Center. N. Engl. J. Med. 256:1128-1134.

39. Stein, M. A., S. D. Mills, and B. B. Finlay. 1994. Salmonella: now you see it now you don't. Bioessays 16:537-538.

40. Tite, J. P., G. Dougan, and S. N. Chatfield. 1991. The involvement of tumor necrosis factor in immunity to Salmonella infection. J. Immunol. 147:31613164

41. Vidal, S., M. L. Tremblay, G. Govoni, S. Gauthier, G. Sebastiani, D. Malo, E. Skamene, M. Olivier, S. Jothy, and P. Gros. 1995. The Ity/Lsh/Bcg locus: natural resistance to infection with intracellular parasites is abrogated by disruption of the Nramp1 gene. J. Exp. Med. 182:655-666.

42. Vidal, S. M., D. Malo, K. Vogan, E. Skamene, and P. Gros. 1993. Natural resistance to infection with intracellular parasites: isolation of a candidate for Bcg. Cell 73:469-485.

Editor: R. E. McCallum 